\title{
RESEARCH ACTIVITIES OF FUTURE TEACHERS OF TECHNOLOGIES AT THE ELECTRICAL ENGINEERING CLASSES
}

\author{
Liubov Pavliuk ${ }^{1}$, Mykola Pryhodii', \\ $1 \mathrm{PhD}$ in Pedagogy, postdoctoral student of the Department of methodology theory for technological education, technical \\ drawing and computer-generated graphics National Pedagogical Dragomanov University \\ http://orcid.org/0000-0003-0607-824X, ResearcherID: G-3623-2019 \\ e-mail: lubov-vp@ukr.net \\ 2 DSc in Education, Professor, Head of the Electronic Learning Resources Laboratory of the Institute of Vocational Education \\ and Training of NAES of Ukraine \\ http://orcid.org/0000-0001-5351-0002, ResearcherID: F-7366-2019 \\ e-mail: prygodii@ukr.net
}

\begin{abstract}
The article proves that the formation of research competence of future technology teachers depends on the methodology and organization of educational, cognitive and research activity of students and on the formation of their educational and research skills. It is substantiated that the importance in the system of future technology teachers training belongs to laboratory, practical, laboratory-practical and individual occupations, as well as consultations with the teacher. At these classes, consolidation of theoretical knowledge, the formation of skills in the installation and operation of electrical equipment, the mastery of the apparatus and algorithms for scientific research. It is established that in the laboratory and practical classes it is necessary to focus the attention of future teachers on problem tasks for activating their search activity. Under such conditions, a situation arises when choosing the knowledge that enables the task to be properly resolved. Creative tasks encourage students to independently search for different ways of solving problems of educational and production character, assumptions, formulating hypotheses, implementing purposeful attempts to confirm them, rejecting some unsuccessful hypotheses, and replacing others with consistent considerations. It is noted that modern methodological and technical support of laboratory classes in different disciplines is designed for an abstract average student and does not always meet the requirements for organizing a developing, creative process. Significant potential for the formation of research competence of future technology teachers is concentrated in the system of laboratory classes in electrical engineering. It is proved that in order to stimulate the research activity of students, it is necessary to set the research objective in laboratory lessons, to introduce into the program of work the problem of creative character, which allows to direct laboratory work in the educationalresearch direction. The characteristic of criteria, indicators and levels of assessment of research competence of future technology teachers is revealed. The results of experimental research are presented.
\end{abstract}

Keywords: research competence; electrical engineering; laboratory lesson; creative tasks, technology teacher.

Introduction. State development depends on the effectiveness of preparing the younger generation for work. The modern labor market is, to a lesser degree, in need of simple executors and increasingly demands the worker as a creative, extraordinary person capable of searching for innovations and introducing them into their own professional activities.

The development of such abilities of the younger generation occurs in the system of general education under the guidance of teachers. An important role in this process belongs to the technology teacher, it is he who thoroughly prepares young people for future professional activities in the field of material production. But in order to develop a creative personality, the teacher must own by himself the basics of creative activity and scientific research. Thus, the problem of the inclusion of future technology teachers in the research system, the development of such 
competencies, which allow solving professional problems by research, becomes a matter of particular importance. As a consequence, in the system of technological education, the research activity of students and the creative approach to solving their educational tasks are becoming more and more important.

A broad field for organizing research activities of students is revealed at the lessons of "Electrical Engineering", since when studying it is necessary to operate both macro and micro objects, which can be observed directly (rotor speed, the motion of a contact pair, etc.) or you can only imagine (electric current, magnetic field, etc.). All these processes are clearly described by mathematical formulas.

Materials. In the institutions of higher education, there is a problem not only in raising the level of theoretical knowledge in educational disciplines, but also in the ability to use them for solving professional problems through research. B. Gershunskyi, N. Nychkalo, D. Chernylevskyi, H. Romanova and others emphasize this. Teachers and psychologists studied the problem of organizing the students' creative and research activities: H. Artemchuk, O. Berezan, M. Hlovin, H. Klovak, M. Kniazian, S. Kopelchak, P. Luzan, A. Nizovtsev, V. Sheiko, O. Rohozina, L. Romanov and others. The theoretical basis of the research is the works concerning: the issues of creativity of students (H. Altshuller, V. Andreev, D. Bogoiavlenskyi, L. Vyhotskyi, V. Druzhynin, Edvard de Bono, V. Nikitina, V. Razumovskyi, S. Rubinshtein, Y. Ponomarov); the formation of research skills in the professional training of specialists (S. Balashov, V. Borysov, I. Katashynska, V. Lytovchenko, N. Nedodatko, V. Sydorenko); the formation of professional skills and abilities (P. Halperin, V. Davydov, A. Leontev, N. Talyzina, A. Tykhomyrov, B. Likhachov, E. Millerian, M. Pryhodii, M. Skatkin, D. Tkhorzhevskyi). Recently, the attention of scholars is also emphasized on the emergence of an acute need for education, which will ensure the formation of research skills, the organization of educational, cognitive and research activities of students (L. Kondrashova, H. Hrannyk, E. Spitsyna, A. Usova). S. Arkhanhelskyi, E. Zlotnykov, M. Klarin, V. Moliako, V. Uspenskyi and others considered the use of various types of tasks as a means to achieve the goals of the educational process and the formation of research skills.

With the unconditional importance of these studies, it should be noted that the problem of forming the research competence of future technology teachers in the study of electrical engineering has not yet been adequately reflected in scientific researches. Therefore, there is a need for further analysis of the issues of organizing the research activities of future technology teachers at electrical engineering classes.
The purpose of the article is the substantiation and experimental verification of the theory of forming the research competence of future technology teachers in the study of electrical engineering.

Methods: analysis, synthesis - for studying educational normative documentation and psychological and pedagogical literature on the research problem; comparison, matching - to compare research approaches to solving the problem of forming of research competence; testing, questioning, observation, conversation - in order to determine the level of formation of research knowledge and skills of students; pedagogical experiment - for the experimental verification of the effectiveness of the developed theory of forming the research competence of future technology teachers; graphical - to illustrate and compare the results of the experiment in graphic forms.

Results and discussions. The presence of advanced research competence in future technology teachers is defined as complex, depending on the nature and conditions of teaching activity, multilevel personality characteristics, containing a system of motives, states, as well as special facilities, research knowledge, skills, which make it possible to substantially improve the quality of the educational process.

Formation of research competence of students depends on the methodic and organization of educational, cognitive and research activities, on the formation of their educational and research skills (Kniazian, 1998; Kopellchak, 1997; Spitsyn, 2003; Romanov, 2013).

Important value in the system of future technology teachers training belongs to laboratory, practical, laboratory-practical and individual occupations, as well as consultations with the lecturer. At these classes, consolidation of theoretical knowledge, the formation of skills and abilities in the installation and operation of electrical equipment, mastery of the apparatus and algorithms for conducting research take place (Pryhodii, 2009; Romanova, 2010; Kulalaeva, 2016, p. 71). In the analysis of studies devoted to the practical training of students, it has been established that in laboratory and practical classes it is necessary to focus the attention of future teachers on problem tasks for activating their search activity. Under such conditions, a situation arises when choosing the knowledge that enables the task to be properly resolved. Creative tasks encourage students to independently search for different ways of solving problems of educational and production character, assumptions, formulating hypotheses, carrying out purposeful attempts to confirm them, rejecting some unsuccessful hypotheses and replacing others for sequential thinking.

It was established that modern methodic and technical support of laboratory lessons from different disciplines is designed for an abstract average student 
and does not always correspond to the requirements for organization of the developing, creative process. Significant potential for the formation of research competence of future technology teachers is concentrated in the system of laboratory classes in electrical engineering.

In order to intensify the research activity of students, it is necessary to establish a research objective in laboratory studies, to introduce a creative task into the program of work, which will make it possible to direct laboratory work in the educational-research course (Pavliuk and Pryhodii, 2016).

The central position of the experimental study is to determine the impact of the developed methodic of conducting laboratory and practical classes on electrical engineering on the formation level of research competence of future technology teachers. The experiment was carried out from 2017 to 2018 and covered more than two hundred students. At the beginning of the experiment, an experimental group (113 people) was created to determine the impact of the proposed methodic. Students of the other group acted as a control group (108 people).

At the ascertaining stage of the experimental study, a control section was conducted with the help of test assignments and a survey of students on the problem of organizing and conducting research activities within the institution of higher education.

Assessment of the research competence of future technology teachers was based on a three-component structure of the criteria and relevant indicators: cognitive (knowledge of the organization and conducting research work in the field of electrical engineering); active (ability to manage their own educational activities, ability to assess the suitability of the chosen methods of work tasks that arise in the process of learning); personal (interest in research as an important component of future professional training; interest in increasing research knowledge and skills in the field of electrical engineering under conditions of independent work).

Four levels of evaluation of the research competence of future technology teachers were used (Pavliuk and Pryhodii, 2016):

$\checkmark \quad$ low - the student has partial knowledge and some skills in planning and conducting research work, does not differentiate education and research work, perform research tasks under the direction of a lecturer, does not show interest in research activities;

$\checkmark$ medium - the student has basic concepts of research activity, has basic concepts and has skills in planning and conducting research work, plans to perform research activities on standard algorithms, searches for additional information under the direction of a lecturer, accepts the need for research activities; sufficient - the student has the basic concepts of the requirements for research competence, carries out planning and conducting research work, is a member of problem circles, oriented to independent search for solutions to issues related to research activities.

$\checkmark \quad$ high - the student has knowledge of the specifics of research activities and understands the specifics of the activities of other students, carries out independent planning and research work on the basis of the search for objectively new methodic techniques for him, independently determines the actual issues of increasing his own research training and searches for the optimal ways of its development.

The obtained results of the verification (Fig. 1) made it possible to form a number of conclusions: firstly, the level of formation of research competence in the control and experimental groups is statistically the same; secondly, students of experimental and control groups in the overwhelming majority have a low level of research competence development; Thirdly, the main reason for the low level of research competence of students is the lack of mechanisms for their involvement in research activities in classes.

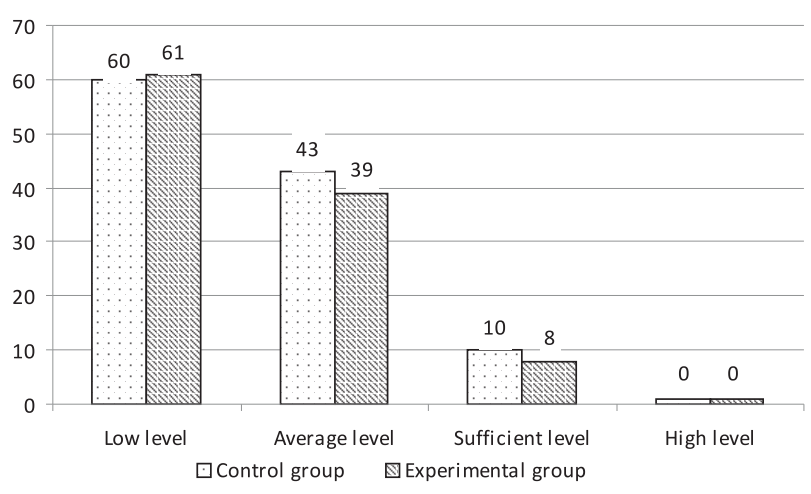

Fig. 1. Levels of development of research competence of future technology teachers (ascertaining stage)

At the formative stage, students of the experimental group became acquainted with the purpose of research activity at each laboratory and practical lesson; were involved in systematic solving of creative tasks and carrying out of search work at carrying out of laboratory works.

At the end of the experiment (after the final certification in the discipline "Electrical Engineering") a control slice was performed, which showed an improvement in the level of research competence in both the control and experimental groups. At the same time, the indicators in the experimental group are higher compared with the control one (Fig. 2). 


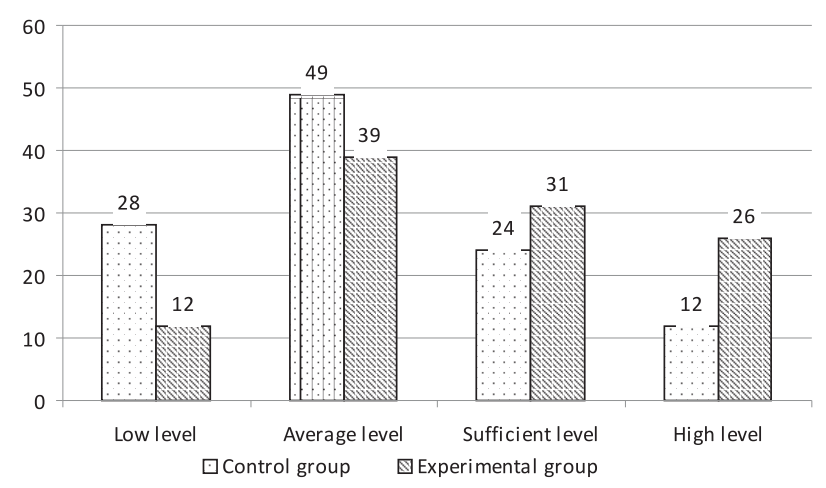

Fig. 2. Levels of research competence development of future technology teachers (forming stage)

Based on the determined indicators of the research competence formation of future technology teachers, the effectiveness of the substantiated methodic of conducting laboratory and practical classes in electrical engineering has been confirmed.
Conclusions. It is proved that the involvement of students in the solution of the system of creative tasks in the planning, control and implementation of search activities, serves as the main element of the formation of research competence. It is revealed that the performance of future technology teachers the laboratory research in electrical engineering is not only a test of theoretical training of students, but also serves as the basis for the formation of research competence. This is due to the fact that with the help of the experiment it is possible to prove the correctness of a previously justified hypothesis, to check the effectiveness of the developed algorithms for solving research problems, during the laboratory work it is necessary to update the research goal, use creative tasks with their subsequent analysis and discussion.

Prospects for further research are to substantiate the concept of developing the research competence of future technology teachers; adjustment the content and methods of student research activity in the context of integration processes in education.

\section{List of references}

Князян, М. О., 1998. Навчально-досліднииька діяльність студентів як засіб актуалізації професійно значущзих знань. Кандидат наук. Ізмаїльський державний педагогічний інститут.

Копельчак, М., 1997. Використання дослідницьких методів навчання у професійній підготовці. Педагогіка $i$ психологія професійної освіти, 3-4, ч.1, с. 197-200.

Кулалаєва, Н., 2016. Проектне навчання як умова набуття досвіду безпечної праці майбутніми будівельниками. Науковий вісник Інституту професійно-технічної освіти НАПН Украӥни. Професійна педагогіка, 12, с. 69-77.

Спіцин, С. С., 2003. Методика організації науково-дослідної роботи студентів у вищому закладі освіти. Київ: Видавничий центр КНЛУ.

Павлюк, Л. В. та Пригодій, М. А., 2016. Теоретико-практичні аспекти формування дослідницьких умінь у майбутніх бакалаврів енергетики агропромислового виробниитва. Київ: ЦП "КОМПРИНТ".

Пригодій, М. А., 2009. Проблеми профільного навчання з електротехніки в загальноосвітніх навчальних закладах: монографія. Чернігів: ЧДПУ імені Т.Шевченка.

Радкевич, В. О., 2012. Компетентнісний підхід до забезпечення якості професійної освіти і навчання. В: Науково-методичне забезпечення професійної освіти і навчання: матеріали Всеукр. (звіт.) наук.-практ. конф. (23 березня 2012 р., м. Київ ), Київ: Ін-т проф.-техн. освіти НАПН України. Вип. 1, с. 9-15.

Романова, Г.М., 2010. Дидактичне проектування як напрям психолого-педагогічної підготовки викладачів ВНЗ. Вісник НТУ-КПІ. Філософія. Психологія. Педагогіка, 1, с. 219-223.

Романов, Л.А., 2013. Методичні аспекти контролю та оцінювання навчальних проектів. Професійна освіта: проблеми і перспективи, 5, с. 116-119.

\section{Translated \& Transliterated}

Kniazian, M. O., 1998. Navchalno-doslidnytska diialnist studentiv yak zasib aktualizatsii profesiino znachushchykh znan [Teaching and research activity of students as a means of updating professionally meaningful knowledge]: diss. Candidate sciences. Izmailskyi derzhavnyi pedahohichnyi instytut, [in Ukrainian].

Kopelchak, M., 1997. Vykorystannia doslidnytskykh metodiv navchannia u profesiinii pidhotovtsi [Use of research training methods in professional training]. Pedahohika i psykholohiia profesiinoi osvity [Pedagogy and psychology of vocational education], 3-4. Ch.1, s. 197-200, [in Ukrainian].

Kulalaieva, N., 2016. Proektne navchannia yak umova nabuttia dosvidu bezpechnoi pratsi maibutnimy budivelnykamy [Project training as a condition for gaining experience of safe work by future builders]. Naukovyi visnyk Instytutu profesiinotekhnichnoi osvity NAPN Ukrainy. Profesiina pedahohika [The Scientific Journal of the Institute for Vocational Education of NAES of Ukraine], 12, s. 69-77, [in Ukrainian].

Spitsyn, Ye. S., 2003. Metodyka orhanizatsii naukovo-doslidnoi roboty studentiv u vyshchomu zakladi osvity [Organization methodology of research work of students in a higher education institution]. Kyiv: Vydavnychyi tsentr KNL, [in Ukrainian].

Pavliuk, L. V. ta Pryhodii, M. A., 2016. Teoretyko-praktychni aspekty formuvannia doslidnytskykh umin u maibutnikh bakalavriv enerhetyky ahropromyslovoho vyrobnytstva [Theoretical and practical aspects of the research skills formation in future bachelors of energy in agro-industrial production]. Kyiv: TsP "KOMPRYNT", [in Ukrainian]. 
Pryhodii, M.A., 2009. Problemy profilnoho navchannia z elektrotekhniky v zahalnoosvitnikh navchalnykh zakladakh [Problems of profile education in electrical engineering in general education institutions]. Chernihiv: ChDPU imeni T.Shevchenka, [in Ukrainian].

Radkevych, V. O., 2012. Kompetentnisnyi pidkhid do zabezpechennia yakosti profesiinoi osvity $i$ navchannia [Competence approach to ensuring the quality of vocational education and training.]. V: Naukovo-metodychne zabezpechennia profesiinoi osvity i navchannia [Scientific and methodical provision of vocational education and training]: materialy Vseukr. (zvit.) naukr.-prakt. konf. (23 Bereznia 2012 r., m. Kyiv ), Kyiv: In-t prof.-tekhn. osvity NAPN Ukrainy. Vyp. 1, s. 9-15, [in Ukrainian].

Romanova, H.M., 2010. Dydaktychne proektuvannia yak napriam psykholoho-pedahohichnoi pidhotovky vykladachiv VNZ [Didactic design as a direction of psychological and pedagogical preparation of lecturers in universities]. Visnyk NTU-KPI. Filosofiia. Psykholohiia. Pedahohika [Bulletin of NTU-KPI. Philosophy. Psychology. Pedagogy],1, s. 219223, [in Ukrainian].

Romanov, L.A., 2013. Metodychni aspekty kontroliu ta otsiniuvannia navchalnykh proektiv [Methodical aspects of monitoring and evaluation of educational projects]. Profesiina osvita: problemy i perspektyvy [Vocational Education: Problems and Prospects], 5, s. 116-119, [in Ukrainian].

\title{
Дослідницька діяльність майбутніх учителів технологій на заняттях з електротехніки
}

\author{
Павлюк Любов ${ }^{1}$, Микола Пригодій²,
}

1 кандидат педагогічних наук, докторант кафедри теорії і методики технологічної освіти, креслення та комп'ютерної графіки, Національного педагогічного університету імені М.П. Драгоманова

2 доктор педагогічних наук, професор, завідувач лабораторії електронних навчальних ресурсів Інституту професійнотехнічної освіти НАПН України

Реферат. У статті доведено, що формування дослідницької компетентності майбутніх учителів технологій залежить від методики та організації навчально-пізнавальної та науково-дослідницької діяльності студентів та від сформованості у них навчальних і дослідницьких умінь. Обгрунтовано, що важливе значення в системі підготовки майбутніх учителів технологій належить лабораторним, практичним, лабораторно-практичним та індивідуальним заняттям, а також консультаціям з викладачем. На цих заняттях відбувається закріплення теоретичних знань, формування умінь і навичок з монтажу та експлуатації електроустаткування, оволодіння апаратом та алгоритмами проведення наукових досліджень. Встановлено, що на лабораторних та практичних заняттях слід акцентувати увагу майбутніх учителів на проблемних завданнях для активізації їх пошукової діяльності. За таких умов виникає ситуація вибору тих знань, що дають можливість правильно розв'язати задачу. Творчі задачі спонукають студентів до самостійних пошуків різних способів розв'язання завдань навчальновиробничого характеру, висування припущень, формулювання гіпотез, здійснення цілеспрямованих спроб їх підтвердження, відкидання одних гіпотез, які не справдилися, і заміни іншими, до послідовного міркування. Зазначено, що сучасне методичне і технічне забезпечення лабораторних занять з різних дисциплін розраховано на абстрактного середнього студента і не завжди відповідає вимогам до організації розвиваючого, творчого процесу. Значний потенціал для формування дослідницької компетентності майбутніх учителів технологій зосереджений в системі лабораторних занять з електротехніки. Доведено, що для активізації дослідницької діяльності студентів слід на лабораторних заняттях встановлювати дослідницьку мету, вводити в програму роботи завдання творчого характеру, що дозволяє спрямовувати лабораторні роботи в навчально-дослідницький напрям. Розкрито характеристику критеріїв, показників та рівнів оцінювання дослідницької компетентності майбутніх учителів технологій. Наведено результати експериментального дослідження.

Ключові слова: дослідницька компетентність; проектна діяльність, електротехніка; лабораторне заняття; творчі задачі, учитель технологій. 